\title{
KARAKTERISTIK KIMIA DAN ORGANOLEPTIK PERMEN JELLY RUMPUT LAUT
}

\author{
THE CHEMICAL AND ORGANOLEPTIC PROPERTIES OF SEAWEED JELLY \\ CANDY
}

\author{
Angcivioletta Moniharapon \\ Balai Riset dan Standardisasi Industri Manado \\ Jalan Diponegoro No: 21-22 Manado \\ Pos-el: moniharaponletta@yahoo.co.id \\ Diterima tgl 09-07-2016, Disetujui tgl 02-08-2016
}

\begin{abstract}
ABSTRAK
Permen jelly adalah salah satu bentuk diversifikasi dari rumput laut. Penelitian ini bertujuan untuk mengetahui karakteristik kimia dan organoleptik permen jelly rumput laut. Parameter yang diamati pada penelitian ini meliputi kadar air, kadar abu, gula reduksi, kadar sukrosa dan uji logam berat. Penelitian ini terdiri dari 4 perlakuan yaitu A1B1 (rumput laut 10\%: gelatin 0\%, kemasan polipropilen), A1B2 (rumput laut 10\%: gelatin 0\%, kemasan aluminium foil, A2B1 (rumput laut 10\%: gelatin 5\%, kemasan polipropilen) dan A2B2 (rumput laut 10\% : gelatin 5\%, kemasan aluminium foil). Analisis dilakukan secara dekriptif. Hasil penelitian menunjukkan bahwa karakteristik kimia dari permen jelly rumput laut dengan perlakuan menggunakan gelatin dan tanpa gelatin menghasilkan permen jelly rumput laut yang belum memenuhi standar SNI permen jelly. Uji organoleptic menunjukkan bahwa panelis menyukai permen jelly rumput laut pada semua perlakuan untuk warna, rasa, tekstur dan bau dengan skala 3 - 4 (suka sampai sangat suka).
\end{abstract}

Kata Kunci : Permen jelly, rumput laut, gelatin, kemasan polipropilen

\section{ABSTRACT}

Jelly candy is one of the diversified forms of seaweed products. The study was aimed to determine the chemical and organoleptic properties of seaweed jelly candy. The parameters observed in this study was the chemical properties including moisture content, ash content, reduced-sugar, sucrose content and heavy metals test. The study consisted of four treatments, A1B1 (seaweed 10\%: gelatin 0\%, packed with polypropylene wrapper), A1B2 (seaweed 10\%: gelatin 0\%, packed with aluminum foil wrapper), A2B1 (seaweed 10\% : gelatin 5\%, packed with polypropylene wrapper) and A2B2 (seaweed $10 \%$ : gelatin 5\%, packed with aluminum foil wrapper). Data were analyzed using descriptive method. The results showed that the chemical properties of seaweed jelly candy that is treated with and without gelatin produces seaweed jelly candy that not meets the SNI standards of jelly candy. Panelists like seaweed jelly candy of all treatments for color, flavor, texture and aroma with a scale of 3-4 (likes to really like).

Keyword : Jelly candy, seaweed, gelatin, polypropylene packaging

\section{PENDAHULUAN}

Rumput laut (seaweed) atau alga merupakan bagian terbesar dari tanaman laut dan sebagai salah satu komoditi ekspor yang potensial untuk dikembangkan. Ada empat jenis rumput laut yang bernilai ekonomi tinggi di Indonesia sebagai komoditi ekspor dan juga untuk konsumsi domestik yaitu Eucheuma sp., Gracillaria sp., Gelidium sp., Sargassum sp. dan Hypnea sp. Jenis Eucheuma cottonii dan Eucheuma spinosum merupakan spesies alga merah yang merupakan penghasil karagenan dan merupakan bagian terbesar dari volume ekspor Indonesia [1].

$$
\text { Kandungan dietary fiber dan }
$$
gizinya bermanfaat sebagai antioksidan, antimutagenik, anti koagulan, anti tumor, dan metabolisme lipid. Rumput laut juga sebagai sumber iodium alami yang terbaik $[2,3]$. Kandungan serat (diatery fiber) pada rumput laut bersifat untuk mengenyangkan dan memperlancar proses metabolisme 
tubuh, sehingga sangat baik dikonsumsi penderita obesitas [4].

Pengembangan budidaya rumput laut harus pula diikuti dengan pengembangan industri pengolahannya, karena nilai tambah rumput laut sebagian besar terletak pada industri pengolahannya. Kenyataan menunjukan bahwa industri yang mengolah rumput laut dari bahan baku menjadi bahan setengah jadi maupun bahan jadi belum begitu banyak contohnya di daerah Sulawesi Utara. Di daerah ini begitu banyak pembudidaya rumput laut namun pemanfaatan nilai tambah dari rumput laut belum dilakukan. Mereka menjual rumput laut berupa bahan mentah, sehingga nilai tambah dari rumput laut belum dinikmati oleh petani atau nelayan, produsen, bahkan pemerintah daerah.

Permen jelly merupakan pemen yang dibuat dari air atau sari buah yang berpenampakan jernih, transparan, serta memiliki tekstur dengan kekenyalan tertentu.

Seiring dengan berkembangnya diversifikasi produk olahan rumput laut khususnya dalam bidang pangan maka dalam kesempatan ini kami mencoba untuk menyajikan pemanfaatan rumput laut sebagai sumber bahan pangan satu diantaranya yakni pembuatan permen jelly. Pembuatan permen jelly ini dengan penambahan rumput laut sebagai bahan hidrokoloid. Penelitian ini bertujuan untuk mengetahui sifat kimia dan organoleptik permen jelly rumput laut Eucheuma cottonii.

\section{METODOLOGI}

Bahan yang digunakan adalah rumput laut Eucheuma cottonii, gula pasir, sirup glukosa, gelatin, asam sitrat, esens buah, dan pewarna makanan. Peralatan yang digunakan adalah pisau, blender, timbangan, gelas ukur, pipet, pengaduk, termometer, wadah cetakan, dan alat masak lainnya, serta $\mathrm{pH}$ meter.

Penelitian ini terdiri dari 4 perlakuan, yaitu : A1B1 (rumput laut 10\% tanpa gelatin, dengan kemasan polipropilen), A1B2 (rumput laut 10\% tanpa gelatin dengan kemasan aluminium foil, A2B1 (rumput laut 10\% dengan gelatin, dengan kemasan polipropilene). Parameter pengamatan meliputi kadar air dan kadar abu [5], kadar gula reduksi dan sakarosa [6], dan Uji organoleptik [7]. Penelis terlatih yang melakukan uji organoleptik berjumlah 15 orang. Uji organoleptik yang dilakukan pada penelitian ini adalah uji kesukaan atau uji dengan skala hedonik (empat skala dari sangat suka sampai tidak suka), yang meliputi warna, rasa, bau dan tekstur. Data diolah dan dianalisis secara deskriptif.

\section{Pembuatan Permen Jeli Rumput Laut}

Prosedur penelitian ini dimulai dengan perendaman rumput laut kering dalam wadah selama 24 jam. Setelah itu rumput laut dihaluskan dengan cara diblender sampai menjadi bubur. $200 \mathrm{~g}$ bubur rumput laut selanjutnya dimasak sampai agak kalis. Tambahkan sirup glukosa, sukrosa, asam sitrat, sodium benzoate dan aduk pada suhu $90-95^{\circ} \mathrm{C}$. Apabila campuran sudah merata. Segera tambahkan gelatin sesuai perlakuan. Aduk secara perlahan, kemudian tambahkan essens. Angkat adonan dan tuang di 
cetakan. Dinginkan pada suhu ruang selama 1 jam. Permen selanjutnya dimasukkan dalam pendingin selama 24 jam pada suhu chilling. Setelah itu produk dikeluarkan, dibiarkan selama 1 jam. Produk permen selanjutnya dipotong dan digulingkan pada campuran adonan tepung gula dan tepung tapioka. Permen jelly rumput laut kemudian dikemas dalam 2 jenis kemasan yaitu plastik polipropilen dan aluminium foil. Selanjutnya permen jelly rumput laut yang dihasilkan dari keempat perlakuan dianalisa karakteristik kimia, dan uji organoleptik.

HASIL DAN PEMBAHASAN

\section{Uji Organoleptik Permen Jelly Rumput Laut}

Uji organoleptik yaitu uji dengan menggunakan indera manusia karena penilaiannya didasarkan pada rangsangan sensorik pada organ indera [7]. Uji organoleptik permen jeli rumput laut yang dilakukan pada penelitian ini adalah uji kesukaan atau uji dengan skala hedonik yang terdiri dari empat skala yaitu sangat suka sampai tidak suka. Uji organoleptik meliputi warna, rasa, tekstur dan bau. Hasil uji organoleptik dapat dilihat pada tabel 1 . Parameter warna berkisar antara 3,3-3,8, rasa 3,3-3,5, tekstur 2,9-3,5 dan bau 3,13,6 . Terlihat bahwa permen jeli rumput laut disukai panelis, dengan skala 3 (suka) sampai 4 (sangat suka) untuk keempat perlakuan.

Tabel 1. Nilai Organoleptik permen jelly rumput laut

\begin{tabular}{ccccc}
\hline Perlakuan & Warna & Rasa & Tekstur & Bau \\
\hline A1B1 & 3,8 & 3,4 & 3,4 & 3,2 \\
A1B2 & 3,6 & 3,5 & 3,5 & 3,1 \\
A2B1 & 3,3 & 3,3 & 2,9 & 3,1 \\
A2B2 & 3,6 & 3,5 & 3,2 & 3,6 \\
\hline
\end{tabular}

\section{Karakteristik Kimia Permen Jeli Rumput Laut}

\section{Kadar Air}

Tabel 2 menunjukkan bahwa kadar air permen jelly rumput laut berkisar antara $13,7-15,1 \%$. Kadar air permen jelly rumput laut masih sesuai dengan persyaratan kadar air dalam SNI 3547.2-2008 untuk permen jelly, dengan nilai maksimal $20 \%$. Perlakuan A2B1 dan A2B2 yaitu perlakuan dengan penambahan gelatin cendrung memiliki kadar air yang tinggi. Hal ini disebabkan karena pembentuk gel adalah suatu fenomena atau pengikatan silang antara rantai-rantai polimer sehingga membentuk suatu jala tiga dimensi bersambungan. Selanjutnya jala ini dapat menangkap atau memobilisasi air di dalamnya sehingga dapat membentuk struktur yang kuat dan kaku [8].

Tabel 2. Kadar air permen jelly rumput laut.

\begin{tabular}{cc}
\hline Perlakuan & Kadar Air (\%) \\
\hline A1B1 & $14,5 \pm 0,57$ \\
A1B2 & $13,7 \pm 0,39$ \\
A2B1 & $15,1 \pm 0,28$
\end{tabular}


Kadar Abu

Kadar abu dapat diartikan sebagai jumlah mineral yang terkandung dalam
$14,6 \pm 0,14$

bahan. Kadar abu permen jelly rumput laut dapat dilihat dalam Tabel 3.

Tabel 3. Kadar abu permen jelly rumput laut

\begin{tabular}{cc}
\hline Perlakuan & Kadar Abu (\%) \\
\hline A1B1 & $0,40 \pm 0,02$ \\
A1B2 & $0,38 \pm 0,03$ \\
A2B1 & $0,44 \pm 0,06$ \\
A2B2 & $0,41 \pm 0,02$ \\
\hline
\end{tabular}

Tabel 3 menunjukkan bahwa kadar abu permen jelly rumput laut berkisar antara $0,38-0,44 \%$. Konsentrasi rumput pada keempat perlakuan sama, yaitu $10 \%$, sehingga tidak ada perbedaan kadar abu yang signifikan antara keempat perlakuan. Sumber mineral berasal dari rumput laut yang digunakan. Kadar abu pada permen jelly ini masih sesuai dengan standar mutu permen jelly (SNI 3574.2-2008) dengan nilai maksimal 3,0\%.

\section{Kadar Gula reduksi}

Pada Tabel 4, kadar gula reduksi permen jelly rumput laut berkisar antara $19,39-28,70 \%$. Kadar gula reduksi pada perlakuan A1B1 yaitu 19,39\%, telah memenuhi standar SNI, yaitu maksimal $25 \%$, sedangkan pada perlakuan A2B1, A1B2 dan A2B2 belum memenuhi standar SNI permen jelly. Kadar gula reduksi berkaitan dengan proses inversi sukrosa menjadi gula invert (glukosa dan fruktosa) [9]. Proses inversi dapat dipengaruhi oleh adanya reaksi dari asam, panas dan kandungan mineral. Khusus untuk asam dan panas, secara keseluruhan adalah sama, namun tidak untuk mineral. Bahan dasar dalam penelitian ini adalah rumput laut yang mengandung mineral. Kandungan mineral yang berbeda, dari perlakuan diduga sebagai kofaktor yang dapat meningkatkan proses inversi.

Tabel 4. Kandungan gula reduksi permen jelly rumput laut

\begin{tabular}{cc}
\hline Perlakuan & Gula reduksi (\%) \\
\hline A1B1 & $19,39 \pm 0,12$ \\
A1B2 & $25,38 \pm 1,54$ \\
A2B1 & $28,70 \pm 2,14$ \\
A2B2 & $25,97 \pm 0,58$ \\
\hline
\end{tabular}

\section{Kadar Sukrosa}

Pada tabel 5 terlihat bahwa kadar sukrosa permen jelly rumput laut berkisar antara 30,62-67,54\%. Kadar sukrosa dari semua perlakuan melampaui nilai yang ditetapkan sehingga tidak memenuhi standar mutu permen jelly (SNI 3574.22008) yaitu $\min 27 \%$. Tingginya kadar sukrosa pada peneltian ini diduga karena penggunaan sukrosa dalam adonan 
permen sebanyak $40 \%$ kemudian ditambahkan juga penggunan campuran tepung gula dan tepung tapioka sebagai bahan pembalutan permen [10].

Tabel 5. Kandungan sukrosapermen jelly rumput laut

\begin{tabular}{cc}
\hline Perlakuan & Kadar Sukrosa (\%) \\
\hline A1B1 & $67,54 \pm 2,88$ \\
A1B2 & $31,39 \pm 0,45$ \\
A2B1 & $29,14 \pm 0,69$ \\
A2B2 & $30,62 \pm 0,16$ \\
\hline
\end{tabular}

\section{Cemaran Logam Berat}

Cemaran logam berat antara lain : Timbal $(\mathrm{Pb})$, tembag $(\mathrm{Cu})$, timah $(\mathrm{Sn})$, Raksa $(\mathrm{Hg})$ dan Arsen (As) telah dianalisa pada permen jelly rumput laut. Hasilnya menunjukkan bahwa untuk keempat perlakuan tidak terdeteksi adanya cemaran logam, hal ini berarti rumput laut yang digunakan sebagai bahan utama pembuatan permen jelly ini berasal dari laut yang belum tercemar logam berat.

\section{KESIMPULAN}

Karakteristik kimia dari permen jelly rumput laut untuk keempat perlakuan (menggunakan gelatin dan tanpa gelatin dengan kemasan polipropilen dan aluminium foil) menghasilkan permen jelly rumput laut yang belum memenuhi standar SNI permen jelly. Panelis menyukai permen jelly rumput laut dari keempat perlakuan untuk warna, rasa, tekstur dan bau dengan skala 3-4 (suka sampai sangat suka).

\section{SARAN}

Perlu dilakukan penelitian lanjutan untuk mempelajari pengaruh jenis kemasan terhadap lama penyimpanan dan mutu permen jelly rumput laut.

\section{DAFTAR PUSTAKA}

[1] Anggadiredja JT, Zatnika A, Purwoto $H$, Istini S. Rumput Laut: Pembudidayaan, Pengolahan dan Pemasaran Komoditas Perikanan Potensial. Penebar Swadaya. Jakarta. 2006;20.

[2] Zada A. Pengaruh diet rumput laut Eucheuma sp. terhadap Jumlah Eritrosit Tikus Wistar dengan Diabetes Aloksan (Doctoral dissertation, Medical faculty). 2009.

[3] Wibowo L, Fitriyani E. Pengolahan Rumput Laut (Eucheuma Cottoni) Menjadi Serbuk Minuman Instan. Jurnal Vokasi 8(2):101-109. 2013

[4] Anonim. Seaweed Cocok Bagi Penderita Obesitas. 2011. [Diakses 22 September 2011]. Available from: http://www.balipost.com.

[5] Horwitzs W. Official methods of analysis of the Association of Official Analytical Chemist. Washington, DC: AOAC. 2005.

[6] Sudarmadji S, dan Suhardi $\mathrm{BH}$. Prosedur analisa untuk bahan makanan dan pertanian. Liberty. Yogyakarta. 1997;138.

[7] Soekarto ST. Penilaian organoleptik untuk industri pangan dan hasil pertanian. Bhratara Karya Aksara, Jakarta. 1985.

[8] Pebrianata E. Pengaruh pencampuran kappa dan iota karagenan terhadap kekuatan gel dan viskositas karagenan campuran. Skripsi. IPB Bogor. 2005

[9] Santoso D. Pemanfaatan rumput laut Gelidium sp. dalam pembuatan permen jelly. Institut Pertanian Bogor. Bogor. 2007

[10] Lees R. Sugar confectionery and chocolate manufacture. Springer Science \& Business Media; 2012 Dec 6. 
